\title{
Fine structure of the female reproductive ducts of Cyathocephalus truncatus (Cestoda: Spathebothriidea), from salmonid fish
}

\author{
Larisa G. Poddubnaya ${ }^{1}$, John S. Mackiewicz ${ }^{2}$, Magdaléna Bruňanská ${ }^{3,4}$ and Tomáš Scholz ${ }^{3}$ \\ ${ }^{1}$ Institute of Biology of Inland Waters, Russian Academy of Sciences, 152742 Borok, Yaroslavl Province, Russia; \\ ${ }^{2}$ Department of Biological Sciences, State University of New York, Albany, NY 12222, USA; \\ ${ }^{3}$ Institute of Parasitology, Academy of Sciences of the Czech Republic, Branišovská 31, 37005 České Budějovice, Czech \\ Republic; \\ ${ }^{4}$ Parasitological Institute, Slovak Academy of Sciences, Hlinkova 3, 04001 Košice, Slovakia
}

Key words: Cyathocephalus truncatus, ultrastructure, ovary, uterus, associated female ducts and glands, cestode evolution

\begin{abstract}
The fine structure of the ovary, ovicapt, oviduct, fertilisation canal, vitelline ducts, vitelline reservoir, ovovitelline duct, ootype and Mehlis' gland, and proximal, middle and distal parts of the uterus of the spathebothriidean cestode, Cyathocephalus truncatus (Pallas, 1781), from salmoniform fish, has been studied for the first time by transmission electron microscopy (TEM). Emphasis was given to characteristics which might shed light on the unclarified phylogenetic position of spathebothriideans, belonging among the most basal tapeworms (Eucestoda). New for cestodes is the finding of a multinucleate cell that plugs the ovicapt lumen. The morphology of the proximal part of the oviduct resembles that of the pseudophyllidean tapeworm Diphyllobothrium latum. After fertilisation in the fertilisation canal, vitellocytes of $C$. truncatus become associated with fertilized oocytes in the ovovitelline duct. Only one type of Mehlis' gland secretory cell is present. The eggs with electron-dense eggshells containing large pores first appear in the proximal part of the uterus. The middle portion of the uterus has well-developed uterine glands. The distal portion of the uterus has apical microtriches. Ultrastructural data on the female genital system of $C$. truncatus are compared and discussed with those for other cestodes. However, on the basis of available ultrastructural data it is not possible to conclude whether the Spathebothriidea are phylogenetically closer to the Caryophyllidea or to the Pseudophyllidea.
\end{abstract}

The Spathebothriidea is a small group of unique tapeworms (Eucestoda) possessing a polypleuroid body, i.e., a body composed of serial repetition of sets of reproductive organs which are not organized in proglottids (Mackiewicz 2003). They parasitize primarily primitive teleosts (sturgeons), salmonids and some marine fish (pleuronectids, soleids) (Gibson 1994). They have a scolex different from that of other cestodes and, in the case of Cyathocephalus truncatus (Pallas, 1781), there is a tendency for a monoxenous life cycle in the amphipod intermediate host (Protasova and Roytman 1995, Okaka 2000, Mackiewicz 2003). Phylogenetic relationships of spathebothriideans to other cestodes remain unclear. They have been classified either as a separate order presumably related to the monozoic (monopleuroid) Caryophyllidea (Hoberg et al. 1997, 2001, Mariaux 1998), or as a family of pseudophyllidean cestodes that have a well-developed strobila composed of proglottids (Dubinina 1987, Protasova and Roytman 1995). Recent molecular analyses (Olson and Caira 1999, Kodedová et al. 2000) have placed spathebothriideans basal to all "true" cestodes (Eucestoda); however, subsequent analyses have not confirmed this conclusion (Olson et al. 2001).

Undoubtedly, the position of the Spathebothriidea and their relationships to other basal cestodes, such as monozoic caryophyllideans and polyzoic pseudophyl- lideans and haplobothriids, should be clarified to better understand the evolution of cestode life cycles and the origin of strobilisation (Beveridge 2001, Mackiewicz 2003). Considering the necessity of searching for new morphological, ultrastructural and life-cycle criteria suitable for the assessment of relationships of the basal groups (Mariaux 1996, Hoberg et al. 1997, 2001, Justine 1998, Beveridge 2001, Olson et al. 2001), information about ultrastructure of the reproductive systems of the different cestode groups, is potentially important for phylogenetic analyses (Justine 1998, Świderski and Xylander 2000, Świderski et al. 2004, Bruňanská et al. 2003a, b).

In a previous paper (Poddubnaya et al. 2005), ultrastuctural observations were presented on the male reproductive system, vagina and seminal receptacle of adult Cyathocephalus truncatus from salmonid fish. In the present study: (i) remaining parts of the female genital system of $C$. truncatus are described; (ii) the uterine glands are compared with those of progenetic forms of another spathebothriidean, Diplocotyle olrikii Krabbe, 1874, from the amphipod Gammarus oceanicus (Davydov et al. 1997); and (iii) the data are placed within a phylogenetic context, with emphasis on a comparison with related cestode groups, especially the caryophyllideans and pseudophyllideans. 


\section{MATERIALS AND METHODS}

Adult Cyathocephalus truncatus were recovered from the pyloric caeca of grayling (Thymallus arcticus baicalensis Dybowski) from Lake Baikal (Russia). The worms were processed as described in a previous paper (Poddubnaya et al. 2005). Briefly, the tapeworms were fixed with $3 \%$ glutaraldehyde in $0.1 \mathrm{M}$ phosphate buffer $(\mathrm{pH} 7.4)$ for $6 \mathrm{~h}$ at $4^{\circ} \mathrm{C}$, postfixed with $1 \%$ osmium tetroxide in $0.1 \mathrm{M}$ phosphate buffer for $1 \mathrm{~h}$ at $4^{\circ} \mathrm{C}$, dehydrated in acetone and embedded in Araldite or Epon. Semithin sections were cut on a Reichert ultramicrotome, stained with methylene blue and examined under a light microscope for identification of different parts of the female genital systems. Ultrathin sections were stained with uranyl acetate and lead citrate and examined in a JEOL JEM-100 C transmission electron microscope operating at 80 $\mathrm{kV}$.

\section{RESULTS}

The female reproductive system of Cyathocephalus truncatus consists of the ovary, uterus, vitelline follicles, vagina with seminal receptacle and associated ducts (Fig. 1).

\section{Ovary}

The ovary is bilobed and located centrally. It is surrounded by a thin wall of a syncytial epithelium that has numerous long, narrow processes between the closely packed germ cells (Figs. 3, 7). As a rule, the oocytes have a large nucleus and little cytoplasm in its first stage of development and are found in a peripheral position of the ovary. Oocytes of successive stages of development fill most of the inner part of the ovary (Figs. 2, 7). They may be ovoid or irregular in shape, but all have a large nucleus with a prominent nucleolus and a cytoplasmic volume larger than that of earlier oocyte stages. Their cytoplasm contains abundant free ribosomes and mitochondria, as well as rough endoplasmic reticulum (Figs. $2,7)$. Large mature oocytes are found centrally in the ovary. They are spherical and are characterised by a large nucleus and nucleolus and cytoplasm with numerous mitochondria, free ribosomes, rows of endoplasmic reticulum, Golgi complexes and, in particular, a few spherical electron-dense cortical granules (Figs. 4, 5, 7).

\section{Ovicapt}

The ovicapt or oocapt is extended from the middle of the posterior edge of the ovarian isthmus. As a small duct-like structure it extends from the ovary and is filled by a syncytium (Figs. 1, 5-7) that has five or more nuclei, abundant mitochondria, ribosomes, and less common rows of rough endoplasmic reticulum. A mature

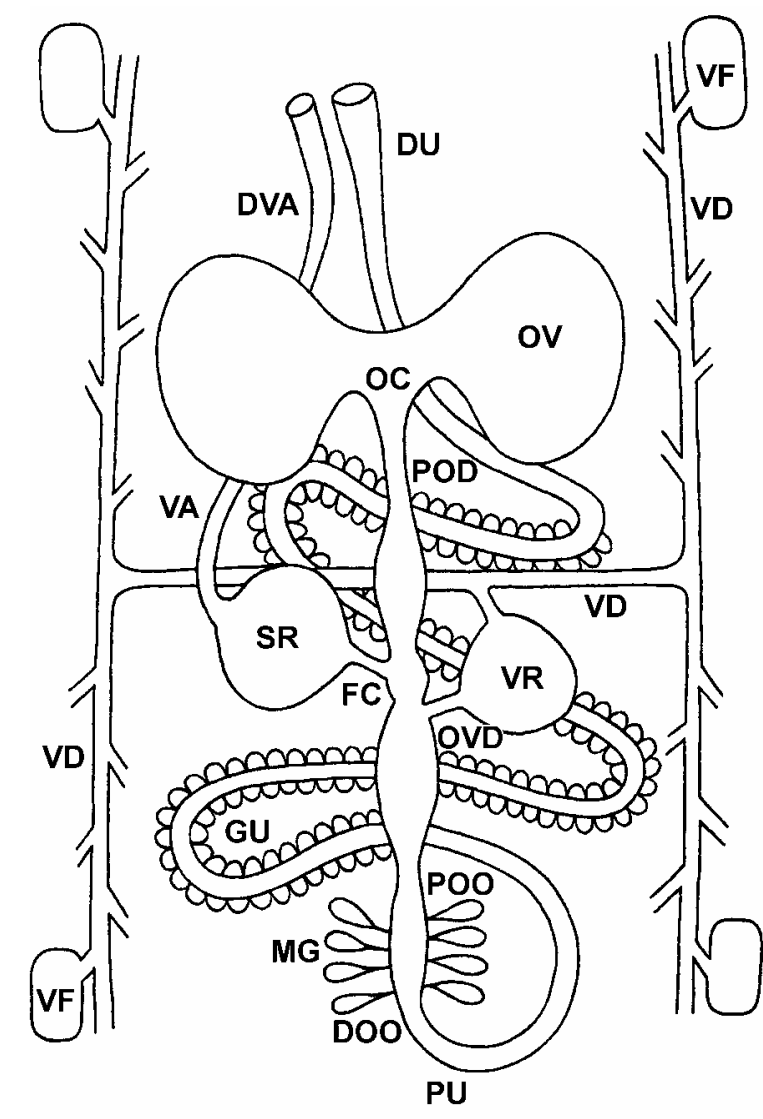

Fig. 1. Diagrammatic representation of the female genital system of Cyathocephalus truncatus. Abbreviations: DOD distal portion of the oviduct; DOO - distal portion of the ootype; DVA - distal portion of vagina; DU - distal portion of uterus; FC - fertilisation canal; GU - glandular uterus; $\mathrm{MG}$ Mehlis' gland; OC - ovicapt; OV - ovary; OVD - ovovitelline duct; POD - proximal portion of the oviduct; POO - proximal portion of the ootype; PU - proximal portion of uterus; SR seminal receptacle; VA - vagina; VD - vitelline duct; VF vitelline follicle; VR - vitelline reservoir.

oocyte is often embedded in the cytoplasm of this syncytium (Figs. 5, 7).

\section{Oviduct}

The structure of the oviduct varies considerably along its length. Its proximal portion starts as a long, narrow tube (Figs. 7,8) lined by a thin layer of epithelial wall containing elongate nuclei with a nucleolus (Fig. 9). The cytoplasm contains numerous vesicles of different sizes and mitochondria. The surface is covered with long, plicate microlamellae that are flexible and bend to the luminal surface (Figs. 9, 10). Mature oo-

Figs. 2-6. Ultrastructure of the ovary and ovicapt of Cyathocephalus truncatus. Fig. 2. Various stages of oocyte development within ovary. Fig. 3. Epithelial process between two closely packed germ cells. Fig. 4. Spherical rows of rough endoplasmic reticulum with electron-dense cortical granules in oocyte cytoplasm. Fig. 5. Syncytium with four nuclei and mature oocyte. Fig. 6. Syncytium within ovicapt lumen. Abbreviations: CG - cortical granules; CS - syncytial cytoplasm; EP - epithelial process; $\mathrm{ER}$ - endoplasmic reticulum; $\mathrm{M}$ - mitochondria; $\mathrm{MO}$ - mature oocyte; $\mathrm{N}$ - nucleus; $\mathrm{OO}$ - oocyte. Scale bars: Figs. $2,5=2$ $\mu \mathrm{m}$; Fig. $3=1 \mu \mathrm{m}$; Fig. $4=0.5 \mu \mathrm{m}$; Fig. $6=5 \mu \mathrm{m}$. 

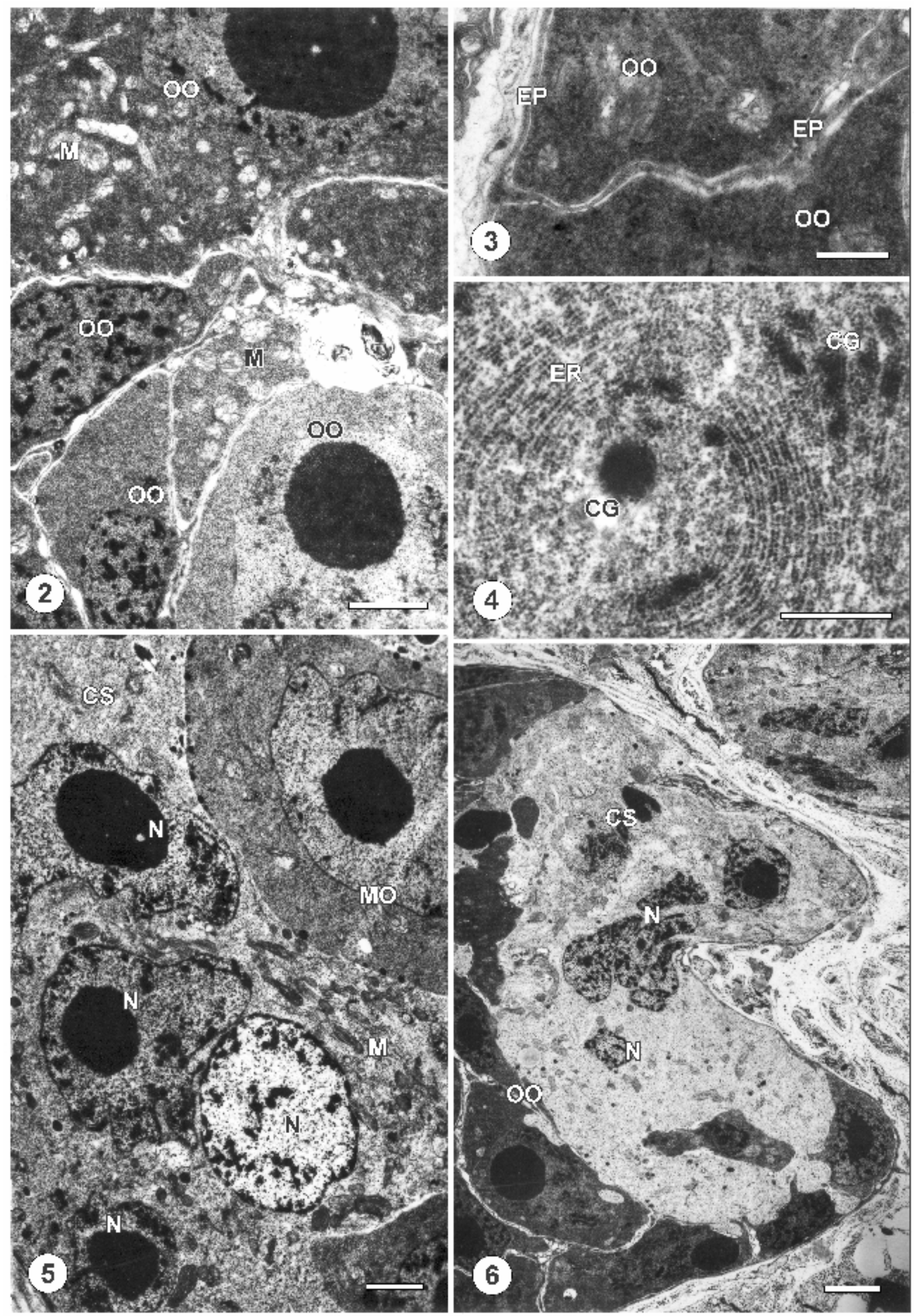
cytes are closely packed in the lumen of the oviduct (Fig. 8). The nucleate epithelial lining of the distal portion of the oviduct is thicker and strengthened by adjacent circular muscles. Long, highly plicate brush lamellae cover the inner surface (Figs. 11-13). The luminal and contraluminal syncytial surfaces are deeply folded into the epithelium of the oviduct. Beneath the epithelial wall is a thin fibrillar layer of basal lamina. The nuclei become prominent and then are eliminated into the duct lumen (Figs. 11-13). The layers of circular muscles increase in number in the terminal portion of the oviduct.

\section{Fertilisation canal}

The short, muscular duct, originating from seminal receptacle (Fig. 14), is connected with fertilisation canal. The strength of the syncytial canal wall is considerably increased by a few, large, elongate nuclei (Fig. 15). Rarely, there may be small, short lamellae on the luminal surface of the canal (Fig. 14). Within the canal, spermatozoa may coil around oocytes and, in some cases, axonemes of spermatozoa are observed within oocytes (Fig. 16).

\section{Vitelline ducts}

Small vitelline ducts originating from vitelline follicles have a thin epithelium covered with apical lamellae and occasional cilia. These small ducts interconnect the vitellaria and join to form larger ducts (Fig. 1). The distal cytoplasmic lining of these large ducts has large nuclei, numerous mitochondria and is covered with lamellae and cilia (Figs. 17, 18). Each cilium has a basal body in the apical portion of epithelial wall (Fig. 18). In cross-sections, cilia have nine regularly arranged peripheral axonemal doublets; the central axonemal core may be present or absent. No rootlets were observed. The contraluminal membrane is folded and rests on a thin basement layer attached to the circular muscles (Fig. 17).

\section{Vitelline reservoir}

The large lateral vitelline ducts join near the ovary to form a voluminous vitelline reservoir (Fig. 1). The lining of this reservoir is syncytial and contains a few small nuclei that are surrounded by cytoplasm with numerous ribosomes and mitochondria (Fig. 19). Unlike the vitelline ducts, cilia are absent and the luminal surface only bears lamellae (Figs. 19, 20). Muscle layers are localised underneath the contraluminal surface (Fig. 20). Within the vitelline ducts and vitelline reservoir, there are numerous fragments of vitelline cells and free globules (Figs. 17, 20). The vitelline reservoir is connected to the oviduct at the distal end of the fertilisation canal that forms the large ovovitelline duct.

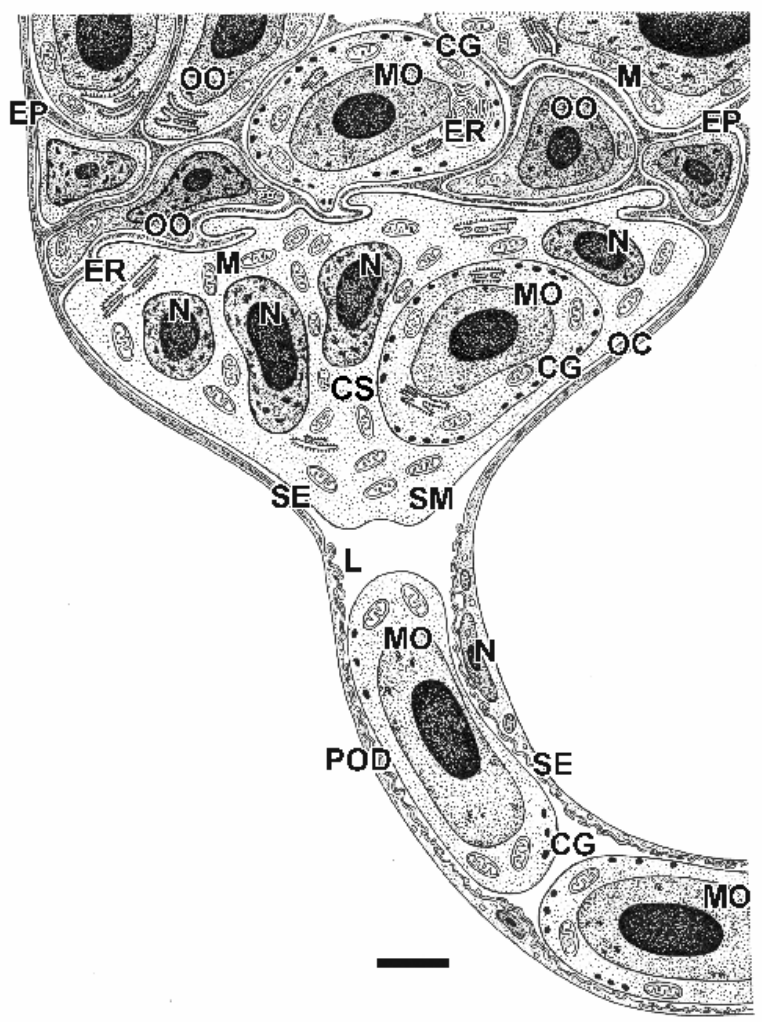

Fig. 7. Diagrammatic representation of the ovicapt of Cyathocephalus truncatus. Abbreviations: $\mathrm{CG}$ - cortical granules; CS - syncytial cytoplasm; EP - epithelial process; ER - endoplasmic reticulum; L - lamellae; $\mathrm{M}$ - mitochondria; $\mathrm{MO}$ mature oocyte; $\mathrm{N}$ - nucleus; OC - ovicapt; OO - oocyte; POD - proximal portion of the oviduct; SE - syncytial epithelium; $\mathrm{SM}-$ syncytium. Scale bar $=4 \mu \mathrm{m}$.

\section{Ovovitelline duct}

The epithelium of the ovovitelline duct is thin except where large, solitary nuclei occur. Though apical lamellae are rare, lamellar processes of the sarcoplasm are present under the epithelial syncytial cytoplasm (Fig. 23). Oocytes, fragments of vitelline cells and free vitelline globules fill the lumen of the ovovitelline duct (Fig. 21). However, free spermatozoa are absent. All oocytes contain remnants of spermatozoa but a part of the tail of the spermatozoa may be found outside their plasma membrane (Fig. 22). Vitellocyte fragments may contain a nucleus and have cytoplasm with free ribosomes and a peripheral electron-dense portion with lipid droplets (Figs. 21, 22, 24). The external boundary of these fragments is covered with thin filiform extensions (Fig. 22)

Figs. 8-13. Ultrastructure of the different portions of the oviduct of Cyathocephalus truncatus. Fig. 8. Long narrow tube of the proximal portion of the oviduct with mature oocyte within lumen. Fig. 9. Nucleus of proximal oviduct epithelium. Fig. 10. Cytoplasm of syncytial epithelial wall of proximal oviduct. Fig. 11. Distal portion of the oviduct and eliminated nuclei within lumen. Fig. 12. Epithelial wall near proximal oviduct tube with nuclei in cytoplasm. Fig. 13. Distal part of the oviduct with prominent nuclei. Abbreviations: L - lamellae; M - mitochondria; ML - muscle layers; MO - mature oocyte; $\mathrm{N}$ - nucleus; SE - syncytial epithelium; V - vesicles. Scale bars: Figs. 8, $13=2 \mu \mathrm{m}$; Figs. 9, 10, $12=1 \mu \mathrm{m}$; Fig. $11=3 \mu \mathrm{m}$. 


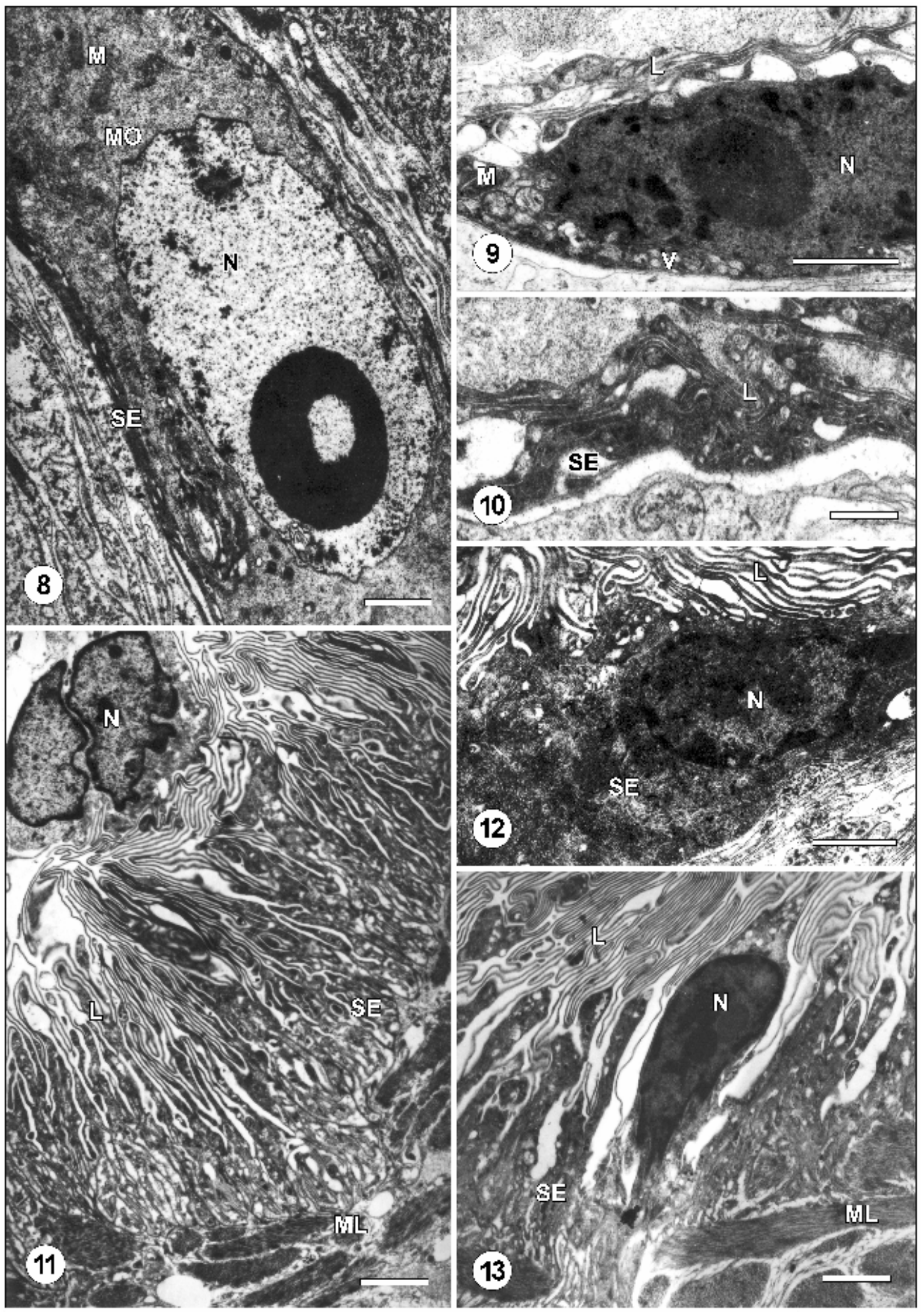




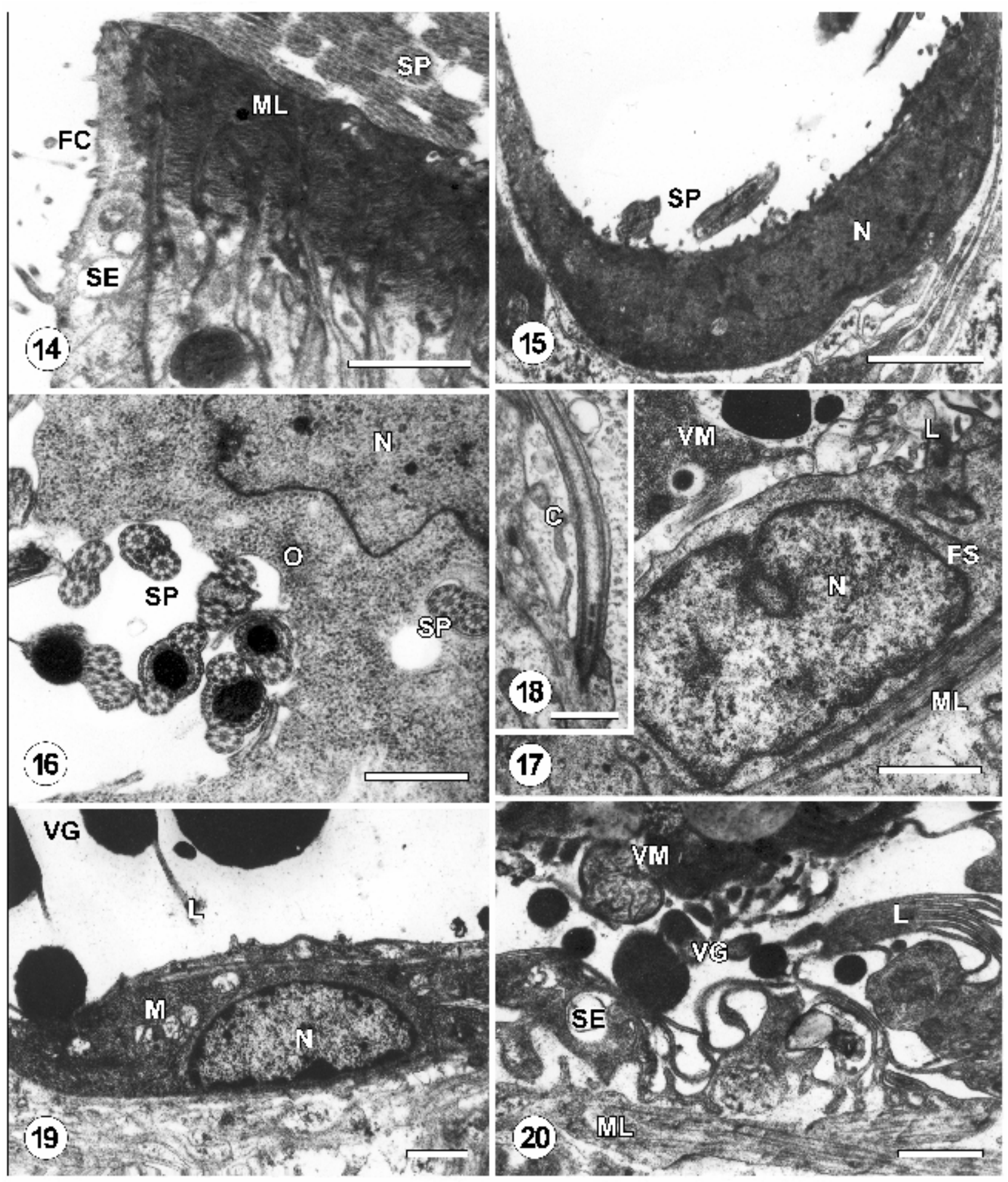

Figs. 14-20. Fine structure of the fertilisation canal, vitelline ducts and vitelline reservoir of Cyathocephalus truncatus. Fig. 14. Junction of seminal receptacle with fertilisation canal. Fig. 15. Large nucleus within syncytial wall of the fertilisation canal. Fig. 16. Mature oocyte with sperm axonemes in cytoplasm and spermatozoa within the lumen of fertilisation canal. Fig. 17. Nuclear region of vitelline duct. Fig. 18. Cilium on the apical surface of vitelline duct. Fig. 19. Nuclear region of vitelline reservoir. Fig. 20. Syncytial wall and lamellae of vitelline reservoir. Abbreviations: C - cilium; FC - fertilisation canal; FS - folded surface; L - lamellae; M - mitochondria; ML - muscle layers; N - nucleus; OO - oocyte; SE - syncytial epithelium; SP - spermatozoa; VG - vitelline granules; VM - vitelline material. Scale bars: Figs. 14, 17-20 =1 $\mu \mathrm{m}$; Fig. $15=2 \mu \mathrm{m}$; Fig. $16=0.5 \mu \mathrm{m}$. 


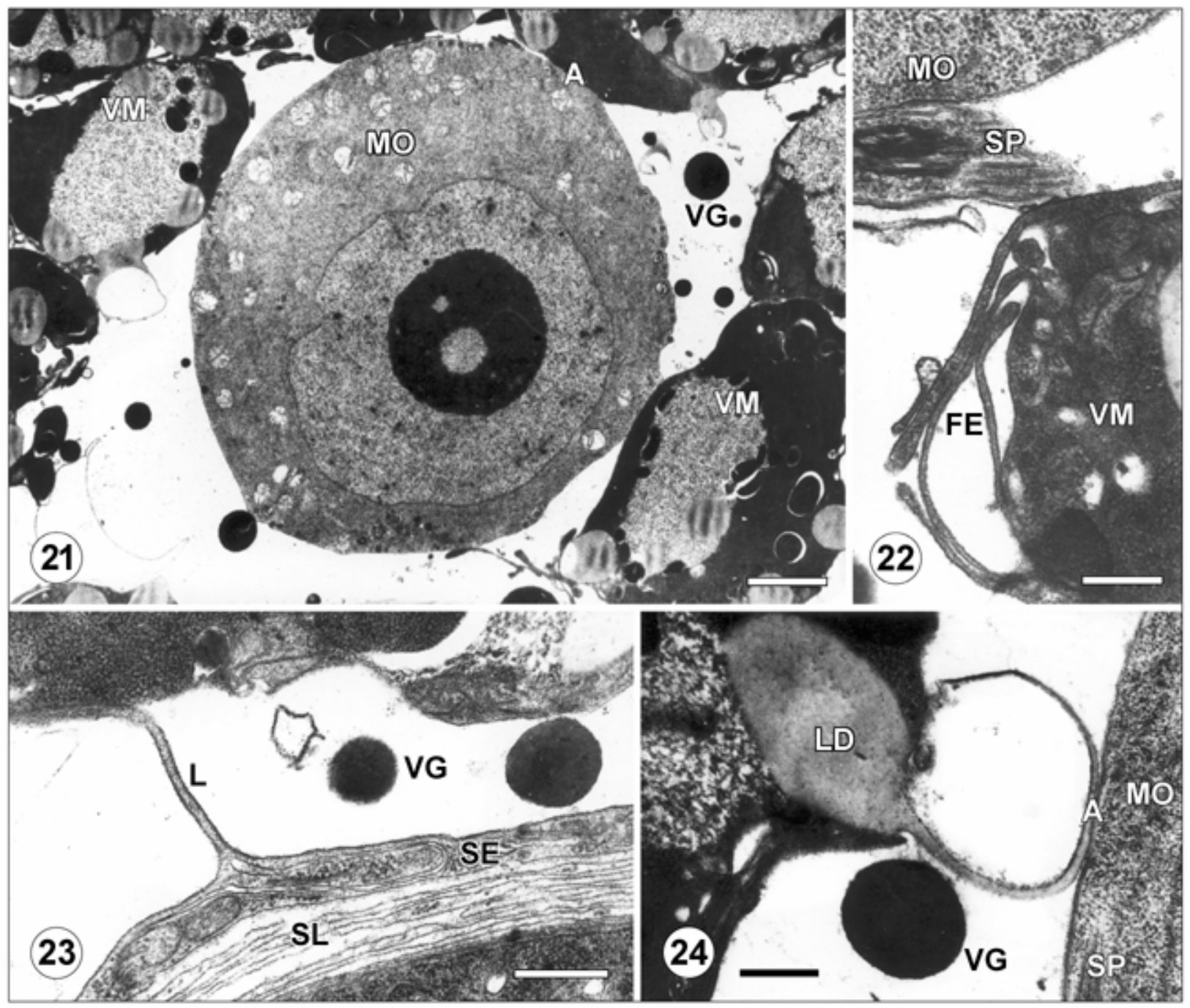

Figs. 21-24. Ultrastructure of the ovovitelline duct of Cyathocephalus truncatus. Fig. 21. Fertilized oocyte, vitelline material and free shell globules within the lumen of ovovitelline duct. Fig. 22. The external boundary of vitelline material with filiform extensions. Fig. 23. Epithelial wall of ovovitelline duct with apical lamellae and sarcoplasma lamellar processes under epithelium. Fig. 24. Prominent lipid droplet of elongate form in junction of oocyte with vitelline cytoplasm. Abbreviations: A - association of oocyte and vitelline cytoplasm; FE - filiform extensions; L - lamella; LD - lipid droplet; MO - mature oocyte; SE - syncytial epithelium; SL - sarcoplasma lamellar processes; SP - spermatozoa; VG - vitelline globules; VM - vitelline material. Scale bars: Fig. $21=3 \mu \mathrm{m}$; Figs. $22-24=0.5 \mu \mathrm{m}$.

and prominent, sometimes elongate lipid droplets (Fig. 24). It is in the ovovitelline duct where the first vitellocytes become associated with fertilized oocytes (Figs. 21, 24).

\section{Ootype and Mehlis' gland}

The ootype consists of a proximal, non-glandular part and a distal portion with Mehlis' gland. It is lined by a folded nucleate syncytium which rests on a layer of fibrous basal lamina that is surrounded by layers of muscular fibres (Figs. 25, 27). The first portion of the proximal part of the wall is unciliated and the apical plasma membrane forms blunt finger-like folds (Fig. 25). The syncytial cytoplasm contains large nuclei, numerous mitochondria and small vesicles (Fig. 25). The folds of contraluminal surface reach into the syncytial epithelial wall (Fig. 25). Closer to the Mehlis' gland, the luminal surface of the proximal region of the ootype is covered by cilia and lamellae that occur infrequently (Fig. 27).

The luminal surface of the distal portion of the ootype is folded and these folds bear long lamellae (Fig. 28). Within the Mehlis' gland complex, glandular cells are arranged at various distances from the ootype wall (Fig. 26). All these unicellular gland cells appear to be of a single type that occurs separated or in groups of up to three cells. Throughout the cytoplasm of these cells, there is an extensive endoplasmic reticulum and abundant granular material (Fig. 29). Mature electron-dense spherical granules are approximately $0.3 \mu \mathrm{m}$ in diameter 


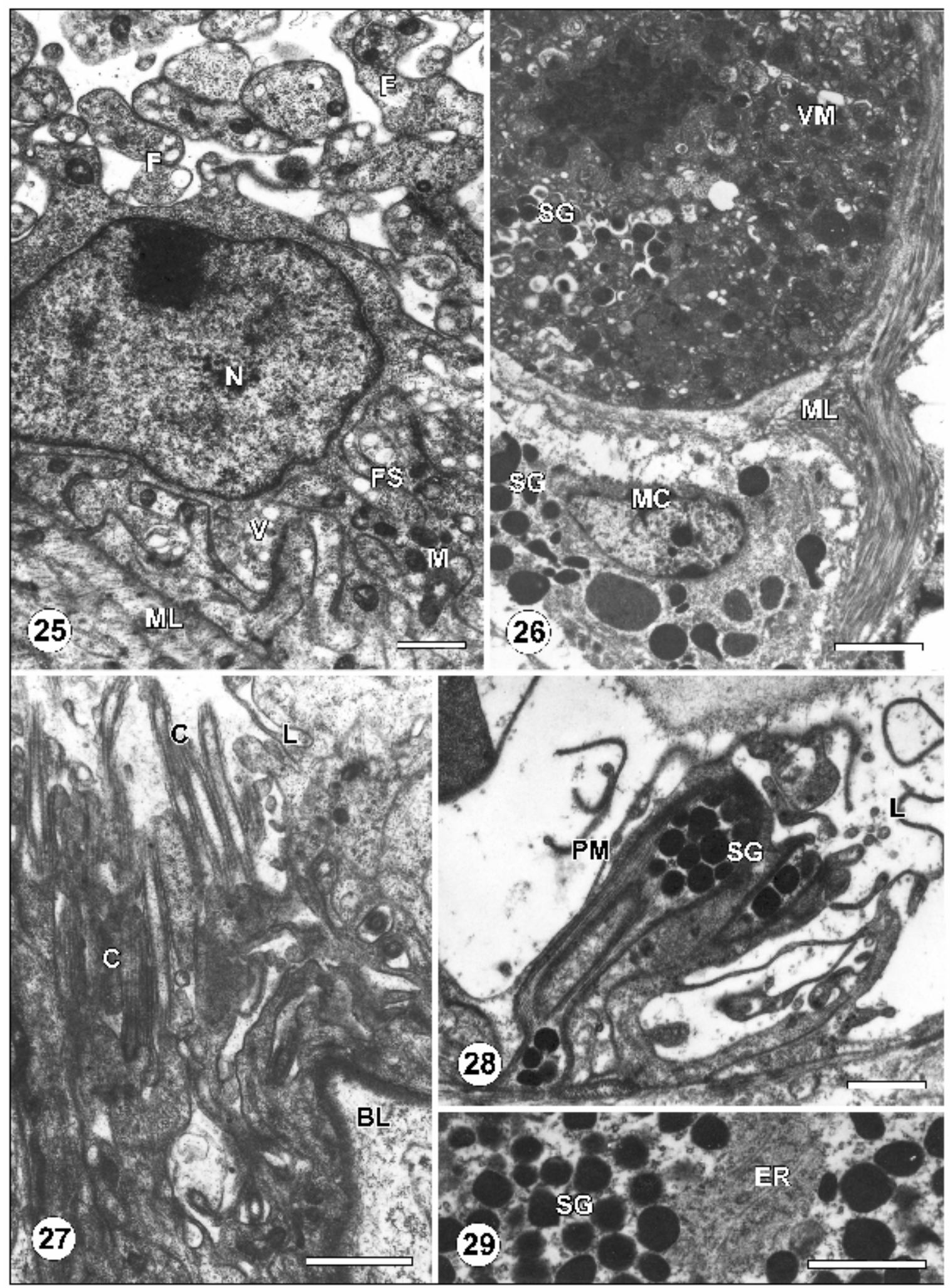

Figs. 25-29. Ultrastructure of the ootype with Mehlis' gland of Cyathocephalus truncatus. Fig. 25. Epithelial wall of the proximal portion of the ootype. Fig. 26. Section of the distal ootype lumen with variety of structures. Fig. 27. Ootype epithelial wall with apical cilia. Fig. 28. Distal portion of the ootype with terminal part of the Mehlis' gland duct. Fig. 29. Cytoplasm of Mehlis' gland with secretory granules. Abbreviations: $\mathrm{BL}$ - basal layer; $\mathrm{C}$ - cilia; $\mathrm{ER}$ - endoplasmic reticulum; $\mathrm{F}$ - folds of apical epithelial cytoplasm; FS - folded surface; L - lamellae; M - mitochondria; MC - Mehlis' gland cell; ML - muscle layers; PM - peripheral microtubules; SG - secretory granules; V - vesicles; VM - vitelline material. Scale bars: Figs. 25, 27-29=1 $\mu \mathrm{m}$; Fig. $26=2 \mu \mathrm{m}$. 


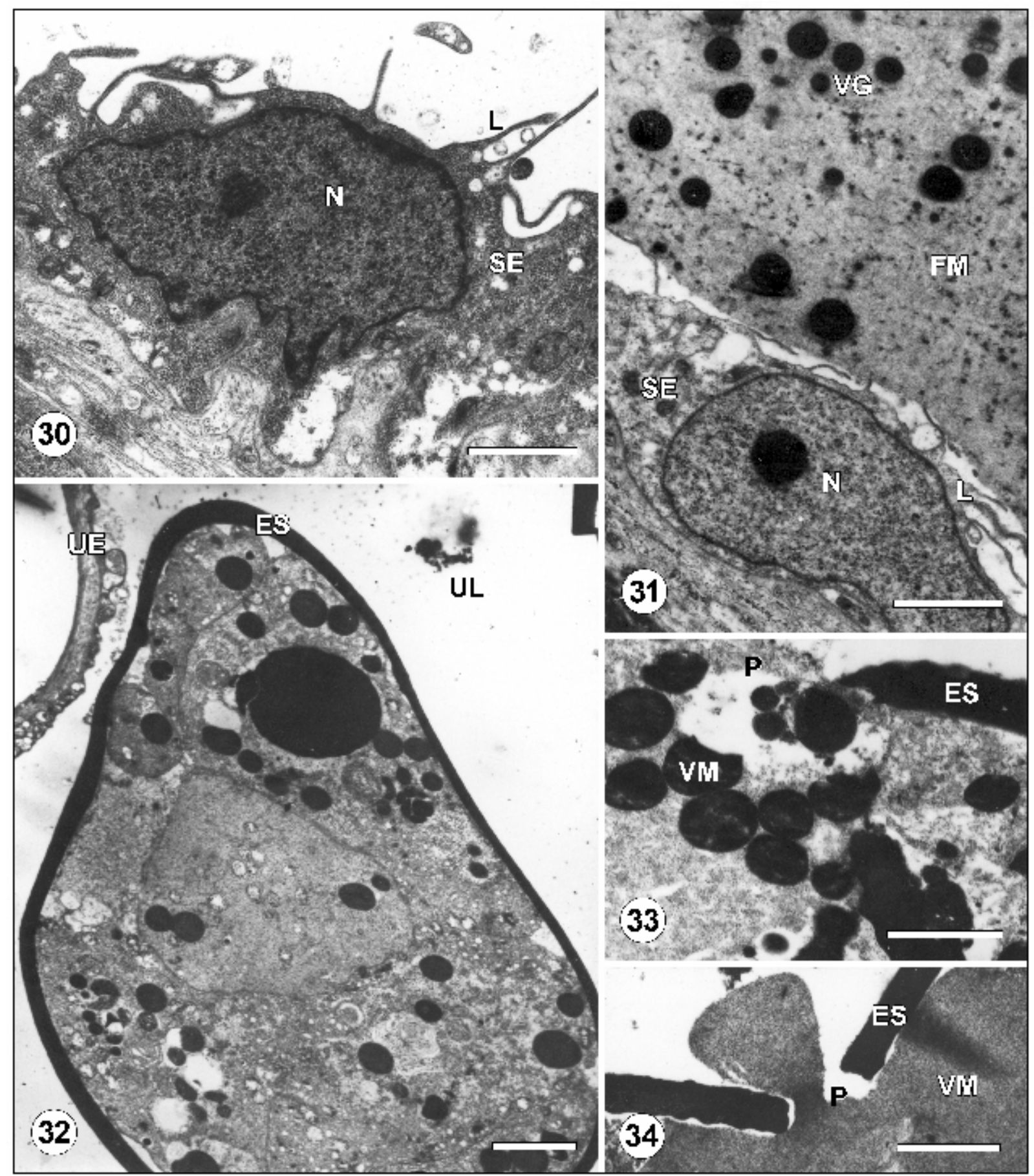

Figs. 30-34. Proximal portion of the uterus of Cyathocephalus truncatus. Fig. 30. Epithelial wall with nucleus. Fig. 31. The initial part of the uterus just outside the ootype with separate eggshell globules mixed among fibrous substance. Fig. 32. The egg with organized dark eggshell within the lumen of the uterus proximal portion. Figs. 33, 34. Vitelline material enters into the egg through large pore of eggshell. Abbreviations: ES - eggshell; FM - fibrous material; L - lamellae; N - nucleus; P - pore; SE syncytial epithelium; UE - uterus epithelium; UL - uterus lumen; VG - vitelline globules; VM - vitelline material. Scale bars: Fig. $30=1 \mu \mathrm{m}$; Figs. $31,33,34=2 \mu \mathrm{m}$; Fig. $32=3 \mu \mathrm{m}$.

(Figs. 28, 29). A ring of peripheral microtubules is evident at the terminal parts of the ducts where they open into the ootype (Fig. 28). Within the distal ootype lumen are what appear to be secretory granules of the Mehlis' gland as well as cytoplasmic inclusions of vitelline cytons (Fig. 26). The ootype merges into the major part of the uterus proper that consists of proximal, middle and distal portions. 

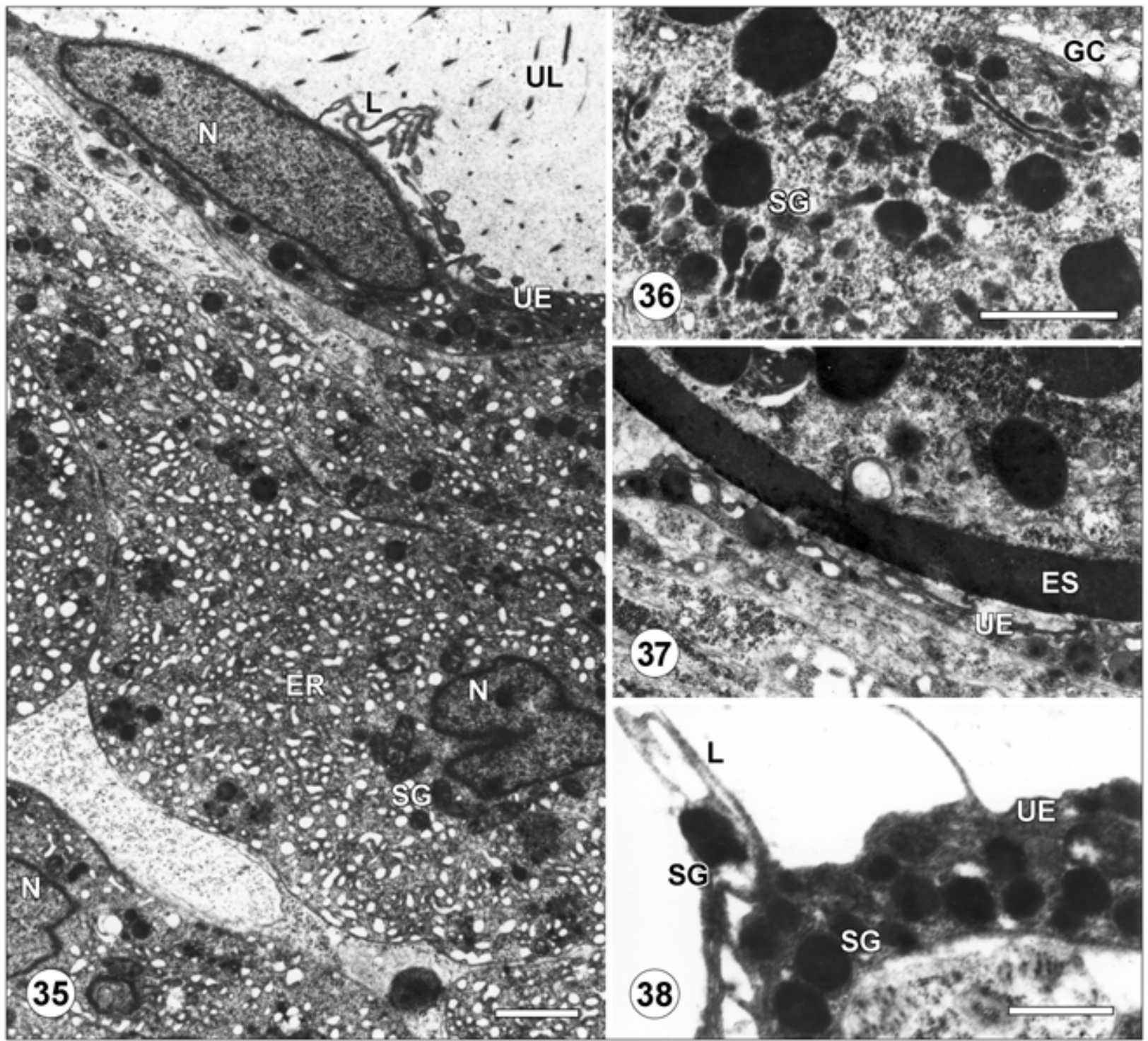

Figs. 35-38. Middle portion of the uterus of Cyathocephalus truncatus. Fig. 35. Glandular cells around epithelial wall of the middle portion of the uterus. Fig. 36. Cytoplasm of glandular cell with formed secretory granules. Fig. 37. Eggshell in close opposition to the uterine wall. Fig. 38. Apocrine secretion of secretory granules of uterine glands. Abbreviations: ER - endoplasmic reticulum; ES - eggshell; GC - Golgi complex; L - lamellae; N - nucleus; SG - secretory granules; UE - uterus epithelium; $\mathrm{UL}-$ uterus lumen. Scale bars: Fig. $35=2 \mu \mathrm{m}$; Figs. $36,38=0.5 \mu \mathrm{m}$; Fig. $37=1 \mu \mathrm{m}$.

\section{Proximal portion of the uterus}

The proximal uterus is non-glandular and has an epithelial wall that merges with that of the ootype. The epithelium is syncytial; it is thin except in perinuclear regions (Fig. 30). The syncytial cytoplasm is filled with free ribosomes, mitochondria and small electron-lucent vesicles. Thin lamellae project into the lumen (Fig. 30). The lumen of the proximal portion of the uterus is filled with many separate vitelline shell globules and a fibrous substance (Fig. 31). The first eggs with an elaborated eggshell and containing oocytes and vitellocytes appear in this part of the uterus (Fig. 32). All eggs have a dark, developed eggshell (Fig. 32) and large pores on the eggshell surface (Figs. 33, 34).

\section{Middle portion of the uterus}

The middle part of the uterine duct is surrounded by numerous glandular perikarya that make up the uterine glands (Fig. 35). The perinuclear cytoplasm of these glandular cytons contains an extensive endoplasmic reticulum with enlarged cisternae, Golgi complexes, and a large number of secretory granules in various stages of development (Figs. 35, 36). Granules are spherical and electron-dense, measuring about $0.60 \times 0.45 \mu \mathrm{m}$. Cytoplasmic bridges fuse glandular cells with the uterine epithelium. The cytoplasm of the syncytial epithelium contains large nuclei as well as the same organelles found in gland cells (Fig. 35). Sinuous lamellae cover the luminal surface (Figs. 35, 38). Discharge of granules 
takes place by merocrine and apocrine secretion (Fig. 38). Eggs are in close contact with the uterine glandular wall (Fig. 37).

\section{Distal portion of the uterus}

The structure of the distal uterus wall resembles that of the tegument, namely, the epithelium contains microtriches and electron-dense bodies (Figs. 39, 42). In addition, there are numerous small vesicles in the epithelial cytoplasm (Figs. 39, 42). In the transition region between the middle and distal uterus the epithelium forms folds, loses the apical lamellae and nuclei are eliminated into the uterus lumen (Figs. 40, 41). Microtriches have the basal part approximately $0.4 \mu \mathrm{m}$ long and the distal one $0.7 \mu \mathrm{m}$ in length. A thin basal lamina and two layers of muscles envelop the distal portion of uterus wall (Fig. 39). At the terminal end of the uterus (uterine pore), there is a muscular sphincter that consists of up to ten well-developed muscle layers (Fig. 43). Eggs that lie within the distal uterine lumen have an electron-dense eggshell that is surrounded by fibrous material of moderate electron density (Fig. 39).

\section{DISCUSSION}

Ultrastructural studies of the female reproductive system of cestodes of the order Spathebothriidea have not been extensive. The earlier studies on Diplocotyle olrikii by Davydov et al. (1997) focused primarily on the middle part of the uterus. The present study provides the first data on most of the female reproductive system of a second species, Cyathocephalus truncatus.

The female reproductive system of $C$. truncatus generally resembles that of the pseudophyllidean Diphyllobothrium latum (Diphyllobothriidae) (Poddubnaya 2002) but it also shares some ultrastructural features with monozoic cestodes (Caryophyllidea) (Davydov and Poddubnaya 1988, Davydov et al. 1994, Poddubnaya 2003b, Poddubnaya et al. 2003).

There is, however, a conspicuous difference in the ultrastructure of the ovicapt of $C$. truncatus from that observed in caryophyllidean and pseudophyllidean cestodes, in which three types have been described. In the first type, known only in the caryophyllidean Caryophyllaeus laticeps, a muscular sphincter helps regulate the passage of mature oocytes (Davydov et al. 1994). In the pseudophyllidean $D$. latum, there is a single cell within the ovicapt lumen that has presumably the same regulatory function (Poddubnaya 2002). The third type is characterised by the absence of a sphincter or a filtering cell and has been described in the caryophyllidean Archigetes sieboldi and pseudophyllidean Eubothrium rugosum (Poddubnaya 2003a, b). Unlike Caryophyllaeus and Diphyllobothrium, all oocytes of Archigetes and Eubothrium appear to be at the same stage of maturity within the ovary and thus there appears to be little regulation or selection of oocytes by the ovicapt.
In C. truncatus, on the other hand, where oocytes are in various stages of maturation, there is a fourth variation in ovicapt structure: here the lumen of the ovicapt is plugged with a syncytium. In this case, the mature oocyte appears embedded in the syncytium when it passes into the oviduct. How this syncytium regulates the passage of oocytes is not completely known. A similar structure of "plug cell" has been described by Tappenden et al. (1993) at the proximal end of the intragermarial tube of the monogenean Entobdella soleae where there are many finger-like processes radiating into the ovary. Such processes do not appear to be present in the ovicapt of $C$. truncatus. These authors suggest that a pressure differential between the ovary and the oviduct or possible amoeboid properties of the oocytes may allow the oocytes to pass through the "plug cell". The singular occurrence of such "plug cell" type of ovicapt in a spathebothriid cestode and a benedeniine monogenean raises important questions of its evolutionary significance.

The oviduct of $C$. truncatus has two morphologically distinct regions: a proximal and a distal one. The proximal region morphologically resembles that of the pseudophyllidean D. latum (Poddubnaya 2002) and the intragermarial tube of the monogenean E. soleae (Tappenden et al. 1993). In all cases the lumen of the duct is filled with mature oocytes that are generally arranged in a single row. Unlike the intragermarial tube of benedeniine monogeneans that may be the site for fertilisation, the proximal part of the oviduct in C. truncatus and D. latum transfer the oocytes to the fertilisation site.

The ultrastructure of the distal region of the oviduct is similar to the fine structure of the oviduct of caryophyllideans (Davydov et al. 1994, Poddubnaya 2003b) and pseudophyllideans (Korneva 2002, Poddubnaya 2002, 2003a). It has long brush lamellae that form a dense mass that serves to prevent sperm from entering the proximal part and ovary (Davydov et al. 1994, Poddubnaya 2002). This duct also has deeply folded luminal and contraluminal membranes and welldeveloped muscular layers. Xylander (1988) showed that the vitelloducts of the Gyrocotylida and Amphilinida have these same deeply folded structures, thus making it well-adapted to expand and accommodate all reproductive products. Within the epithelium of this distal portion of the oviduct of $C$. truncatus, one can find nuclei in central and apical positions before their final elimination into the lumen.

Fertilisation in tapeworms occurs in the oviduct or in the fertilisation canal proximal to the ootype (Świderski and Conn 1999). In C. truncatus, this process seems to take place in the fertilisation canal as demonstrated by the presence of mature oocytes and spermatozoa as well as sperm axonemes within oocytes. The flow of sperm to the fertilisation canal is controlled by a sphincter surrounding the connecting duct from the seminal receptacle. 
The vitelline material in C. truncatus is derived from numerous vesicular vitellaria and stored in a vitelline reservoir that connects with the oviduct, now enlarged to become the ovovitelline duct. In the ovovitelline duct, vitellocytes start to attach to fertilized oocytes. Previous studies have shown that vitellocytes become associated with fertilized oocytes in the oviduct or fertilisation canal in proteocephalideans (Bruňanská 1999, Świderski and Conn 1999, Korneva and Davydov 2001), or in the ootype in D. latum and cyclophyllideans (Yamane et al. 1983, Coil 1991, Świderski and Conn 1999, Świderski et al. 2004).

The initial phase of eggshell formation in C. truncatus takes place in the ootype with the thick shell being formed later at the beginning of the uterus. This part of the uterus is filled with many separate shell globules and mixed with a fibrous substance, probably a secretion of Mehlis' gland. While it has long been acknowledged that Mehlis' gland has a prominent role in eggshell formation, its actual role has yet to be fully understood.

Histochemical, cytochemical and fluorescence microscope studies on secretions of Mehlis' gland in the cyclophyllidean Hymenolepis microstoma, the liver fluke (Fasciola hepatica) and three species of Schistosoma (Moczoń et al. 1992, Schmidt 1996, Colhoun et al. 1998, Moczoń and Świderski 2000, 2002) have shown that the main components of their secretions are carbohydrates, but they have not been characterised in more detail. Colhoun et al. (1998; p. 566) assumed that Mehlis' gland assists in the formation of eggshell by "...providing the alkaline conditions that promote fusion of the shell protein globules and perhaps serving to activate the phenol oxidase enzyme involved in the tanning process".

Three morphologically distinct regions of the uterus of $C$. truncatus have a syncytial wall but only the proximal portion shows the typical cestode uterine structure, i.e., it is lined with an epithelium with prominent ovoid nuclei and apical lamellae (Conn 1993, Conn and Forman 1993, Świderski and Tkach 1997, Davydov and Korneva 2000, Korneva 2001, 2002, Poddubnaya 2002, 2003a). In this part of the uterus, the first eggs with dark eggshell of uniform thickness have been recognized in C. truncatus. The shell at this stage has pores that appear to be similar to those reported in D. latum by Yamane et al. (1983).

The middle and distal portions of the uterus of $C$. truncatus share unique uterine characteristics with both the Caryophyllidea (Davydov and Poddubnaya 1988, Davydov et al. 1994, Poddubnaya 2003b, Poddubnaya et al. 2003) and D. latum (Poddubnaya 2002). As in the spathebothriidean Diplocotyle olrikii and caryophyllidean cestodes, the middle portion of the uterus of $C$. truncatus is lined by prominent uterine glands (Nybelin 1922, Mackiewicz 1972, Protasova and Roytman 1995, Davydov et al. 1997, Kearn 1998, Poddubnaya et al. 2003, present study). In spite of the basic similarity of the glandular middle uterus of caryophyllideans and spathebothriideans, there are ultrastructural differences. The epithelial lining of the glandular portion in C. laticeps and A. sieboldi (Caryophyllidea) is anucleate, while it is nucleate in both spathebothriideans, D. olrikii and C. truncatus (Davydov and Poddubnaya 1988, Davydov et al. 1997, Poddubnaya et al. 2003, present study). The uterine glands of the Caryophyllidea are, therefore, similar in structure to tegumental ones because an anuclear surface region is connected to a subsurface, nucleate glandular one. The cellular pattern is also similar to the distal or "anterior" uterus of Mesocestoides lineatus, which has subsurface cytons supporting an anucleate thin surface layer (Conn 1987). The functional significance of these glands in spathebothriideans may be like that in caryophyllideans, namely the production of a protective, lipoproteinaceous, fibrous coat on the egg surface, as described for C. laticeps (Davydov and Poddubnaya 1988), A. sieboldi (Poddubnaya et al. 2003), and D. olrikii (Davydov et al. 1997). The uterine epithelium in some cyclophyllideans also has a nucleate surface layer that produces material that contributes to protection of the eggs (Conn and Etges 1984).

The ultrastructure of the distal portion of the uterus, with its powerful muscle layers and epithelial microtriches, is basically similar to that of D. latum (Poddubnaya 2002). In the Caryophyllidea (Davydov et al. 1994, Poddubnaya 2003b) as well as in the other pseudophyllidean species (Korneva 2002, Poddubnaya 2003a) this part of the uterus has apical lamellae. A muscular sphincter regulates release of eggs into the host's intestine. The presence of typical tegumental structures in the distal part of the uterus in C. truncatus and D. latum suggests that, unlike the rest of the uterus, it has been formed by an ingrowth from the cestode tegument. A similar mode of differentiation of the cirrus and vagina was described in the tetraphyllidean Phyllobothrium vagans (Phyllobothriidae) by Beveridge and Smith (1985).

Figs. 39-43. Distal portion of the uterus of Cyathocephalus truncatus. Fig. 39. Distal uterine epithelial wall with an egg within the uterus lumen. Fig. 40. Eliminated nucleus and apical lamellae near the distal portion of the uterus. Fig. 41. Closely packed folds of the epithelial wall of the uterine distal portion without eggs in the lumen. Fig. 42. Apical microtriches on the surface of the distal uterine portion. Fig. 43. Muscular sphincter beneath uterus wall of the terminal end of the distal uterine portion. Abbreviations: BP - basal part of microtriches; DB - electron-dense bodies; DP - distal part of microtriches; EN - eliminated nucleus; ES - eggshell; L - lamellae; ML - muscle layers; MT - microtriches; UE - uterus epithelium; UL - uterus lumen; UGM - uterus glandular material; V - vesicles. Scale bars: Figs. $39-41,43=2 \mu \mathrm{m}$; Fig. $42=0.2 \mu \mathrm{m}$. 

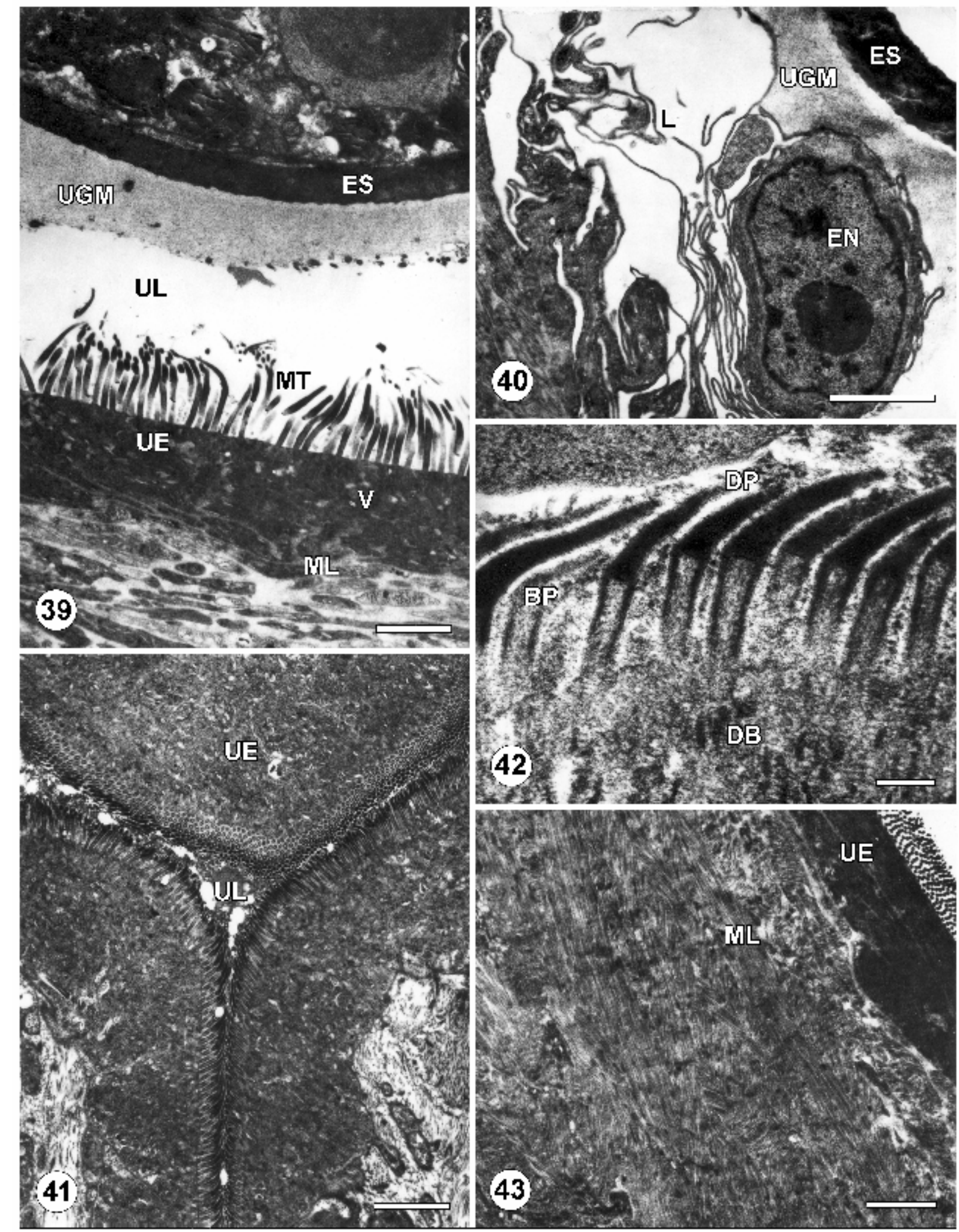
Our studies have shown that the structure of the oviduct and distal portion of the uterus of C. truncatus and $D$. latum are similar to each other. This human parasite, D. latum, was previously placed together with other diphyllobothriids, bothriocephalids, triaenophorids, cephalochlamydids and other cestodes of teleost fish and marine mammals within the Pseudophyllidea (Schmidt 1986, Bray et al. 1994). This order, however, is now shown to be an assemblage of two unrelated clades ("Diphyllobothriidea" and "Bothriocephalidea"), with the former group being more related to caryophyllideans (Mariaux 1998, Kodedová et al. 2000, Olson et al. 2001).

On the other hand, both spathebothriideans (D. olrikii and $C$. truncatus) and the monozoic (monopleuroid) caryophyllideans have a glandular middle uterus. This similarity may be reflected in the presumably most basal position of the Caryophyllidea and Spathebothriidea among eucestodes, as demonstrated by morphological and some molecular analyses (Hoberg et al. 2001, Olson et al. 2001).

While revealing many new morphological differences and similarities, ultrastructural data on the male and female genital system of $C$. truncatus described in the present study and by Poddubnaya et al. (2005) are undecisive as to the placement of spathebothriideans among basal tapeworms. These data thus support the statement of Petkevičiūtè (1996, p. 1213), based on her karyological studies of $C$. truncatus and other cestodes, that the information available "does not exclude the possibility of close phylogenetic relations between Spathebothriidea and Caryophyllidea, as well as between Spathebothriidea and Pseudophyllidea".

Acknowledgements. This study was was supported by the Russian Foundation of Fundamental Research (RFFR), grant no. 05-04-48250, and was undertaken as part of a joint bilateral research program on scientific exchange and cooperation between the Russian and Czech Academies of Sciences. Financial support of the Grant Agency of the Czech Republic to M.B. and T.S. (projects nos. 206/03/1317 and 524/04/0342), the Institute of Parasitology, Academy of Sciences of the Czech Republic (research project Z60220518), and the Grant Agency of the Slovak Republic, VEGA (project no. $2 / 4177 / 04$ ) is acknowledged.

\section{REFERENCES}

BEVERIDGE I. 2001: The use of life-cycle characters in studies of the evolution of cestodes. In: D.T.J. Littlewood and R.A. Bray (Eds.), Interrelationships of the Platyhelminthes. Taylor \& Francis, London, pp. 250-254.

BEVERIDGE I., SMITH K. 1985: An ultrastructural study of the cirrus and vagina of Phyllobothrium vagans (Cestoda: Tetraphyllidea). Z. Parasitenkd. 71: 609-616.

BRAY R.A., JONES A., ANDERSON K.I. 1994: Order Pseudophyllidea Carus, 1863. In: L.F. Khalil, A. Jones and R.A. Bray (Eds.), Keys to the Cestode Parasites of Vertebrates. CAB International, Wallingford, Oxon, pp. 205247.

BRUŇANSKÁ M. 1999: Ultrastructure of primary embryonic envelopes in Proteocephalus longicollis (Cestoda: Proteocephalidea). Helminthologia 36: 83-89.

BRUŇANSKÁ M., NEBESÁŘOVÁ J., SCHOLZ T. 2003a: Spermiogenesis in the proteocephalidean cestode Proteocephalus torulosus (Batsch, 1786). Parasitol. Res. 90: 318-324.

BRUŇANSKÁ M., NEBESÁŘOVÁ J., SCHOLZ T. 2003b: Ultrastructure of the spermatozoon of the proteocephalidean cestode Proteocephalus torulosus (Batsch, 1786). Parasitol. Res. 89: 345-351.

COIL W.H. 1991: Platyhelminthes: Cestoidea. In: F.W. Harrison and B.J. Bogitsch (Eds.), Microscopic Anatomy of Invertebrates. Platyhelminthes and Nemertinea. Vol. 3. Wiley-Liss, Inc., New York, pp. 211-283.

COLHOUN L.M., FAIRWEATHER I., BRENNAN G.P. 1998: Observations on the mechanism of eggshell formation in the liver fluke, Fasciola hepatica. Parasitology 116: 555-567.

CONN D.B. 1987: Fine structure, development, and senescence of the uterine epithelium of Mesocestoides lineatus
(Cestoda: Cyclophyllidea). Trans. Am. Microsc. Soc. 106: 63-73.

CONN D.B. 1993: Ultrastructure of the gravid uterus of $H y-$ menolepis diminuta (Platyhelminthes: Cestoda). J. Parasitol. 79: 583-590.

CONN D.B., ETGES F.S. 1984: Fine structure and histochemistry of the parenchyma and uterine egg capsules of Oochoristica anolis (Cestoda: Linstowiidae). Z. Parasitenkd. 70: 769-779.

CONN D.B., FORMAN L.A. 1993: Morphology and fine structure of the gravid uterus of three hymenolepidid tapeworm species (Platyhelminthes: Cestoda). Invertebr. Reprod. Dev. 23: 95-103.

DAVYDOV V.G., KORNEVA J.V. 2000: Differentiation and structure of a uterus for Nippotaenia mogurndae Yamaguti et Miyato, 1940 (Cestoda: Nippotaeniidea). Helminthologia 37: 77-82.

DAVYDOV V.G., PODDUBNAYA L.G. 1988: Functional morphology of frontal and uterine glands in cestodes of the order Caryophyllidea. Parazitologiya 22: 449-457. (In Russian.)

DAVYDOV V.G., PODDUBNAYA L.G., KOLESNIKOVA G.A. 1994: Ultrastructure of genital system ducts of Caryophyllaeus laticeps (Cestoda, Caryophyllidea). Parazitologiya 28: 501-509. (In Russian.)

DAVYDOV V.G., PODDUBNAYA L.G., KUPERMAN B.I. 1997: An ultrastructure of some systems of the Diplocotyle olrikii (Cestoda: Cyathocephalata) in relation to peculiarities of its life cycle. Parazitologiya 31: 132-141. (In Russian.)

DUBININA M.N. 1987: [Class tapeworms - Cestoda Rudolphi, 1808]. In: O.N. Bauer (Ed.), [Keys to the Parasites of Freshwater Fish Fauna of the USSR. Vol. 3. Parasitic 
Metazoa (second part).] Nauka, Leningrad, pp. 5-76. (In Russian.)

GIBSON D.I. 1994: Order Spathebothriidea Wardle \& McLeod, 1952. In: L.F. Khalil, A. Jones and R.A. Bray (Eds.), Keys to the Cestode Parasites of Vertebrates. CAB International, Wallingford, Oxon, pp. 15-19.

HOBERG E.P., MARIAUX J., BROOKS D.R. 2001: Phylogeny among orders of the Eucestoda (Cercomeromorphae): integrating morphology, molecules and total evidence. In: D.T.J. Littlewood and R.A. Bray (Eds.), Interrelationships of the Platyhelminthes. Taylor \& Francis, London, pp. 112-126.

HOBERG E.P., MARIAUX J., JUSTINE J.-L., BROOKS D.R., WEEKES J. 1997: Phylogeny of the orders of the Eucestoda (Cercomeromorphae) based on comparative morphology: historical perspectives and a new working hypothesis. J. Parasitol. 83: 1128-1147.

JUSTINE J.-L. 1998: Spermatozoa as phylogenetic characters for the Eucestoda. J. Parasitol. 84: 385-408.

KEARN G.C. 1998: Parasitism and the Platyhelminths. Chapman \& Hall, London, $221 \mathrm{pp}$.

KODEDOVÁ I., DOLEŽEL D., BROUČKOVÁ M., JIRKŮ M., HYPŠA V., LUKEŠ J., SCHOLZ T. 2000: On the phylogenetic positions of the Caryophyllidea, Pseudophyllidea and Proteocephalidea (Eucestoda) inferred from $18 \mathrm{~S}$ rRNA. Int. J. Parasitol. 30: 1109-1113.

KORNEVA J.V. 2001: Ultrastructure of the female genital system in Proteocephalus torulosus and P. exiguus (Cestoda: Proteocephalidea). Helminthologia 38: 67-74.

KORNEVA Zh.V. 2002: Ultrastructural organization of reproductive system in Triaenophorus nodulosus (Cestoda, Pseudophyllidea). Zool. Zh. 81: 1432-1438. (In Russian.)

KORNEVA Zh.V., DAVYDOV V.G. 2001: The female reproductive system in the proteocephalidean cestode Gangesia parasiluri (Cestoda, Proteocephalidae). Zool. Zh. 80: 131-144. (In Russian.)

MACKIEWICZ J.S. 1972: Caryophyllidea (Cestoidea): a review. Exp. Parasitol. 31: 417-512.

MACKIEWICZ J.S. 2003: Caryophyllidea (Cestoidea): molecules, morphology and evolution. Acta Parasitol. 48: 143154.

MARIAUX J. 1996: Cestode systematics: any progress? Int. J. Parasitol. 26: 231-243.

MARIAUX J. 1998: A molecular phylogeny of the Eucestoda. J. Parasitol. 84: 114-124.

MARIAUX J., OLSON P.D. 2001: Cestode systematics in the molecular era. In: D.T.J. Littlewood and R.A. Bray (Eds.), Interrelationships of the Platyhelminthes, Taylor \& Francis, London, pp. 127-134.

MOCZOŃ T., ŚWIDERSKI Z. 2000: Schistosoma japonicum: cytochemistry of the Mehlis' gland and the ootype wall. Acta Parasitol. 45: 22-28.

MOCZOŃ T., ŚWIDERSKI Z. 2002: Schistosoma haematobium: cytochemistry of the Mehlis' gland and the ootype wall. Acta Parasitol. 47: 280-287.

MOCZOŃ T., ŚWIDERSKI Z., HUGGEL H. 1992: Schistosoma mansoni: the chemical nature of the secretions produced by the Mehlis' gland and ootype as revealed by cytochemical studies. Int. J. Parasitol. 22: 65-73.
NYBELIN O. 1922: Anatomisch-systematische Studien über Pseudophyllideen. Göteborgs Kungl. Vetenkaps-och. Viterhets-Samhalles Handlingar, Fjärde Följden, 26, 228 pp.

OKAKA C.E. 2000: Maturity of the procercoid of Cyathocephalus truncatus (Eucestoda: Spathebothriidae) in Gammarus pulex (Crustacea: Amphipoda) and the tapeworm's life cycle using the amphipod as the sole host. Helminthologia 37: 153-157.

OLSON P.D., CAIRA J.N. 1999: Evolution of the major lineages of tapeworms (Platyhelminthes: Cestoidea) inferred from $18 \mathrm{~S}$ ribosomal DNA and elongation factor-1 $\alpha$. J. Parasitol. 85: 1134-1159.

OLSON P.D., LITTLEWOOD D.T.J., BRAY R.A., MARIAUX J. 2001: Interrelationships and evolution of the tapeworms (Platyhelminthes: Cestoda). Mol. Phyl. Evol. 19: 443-467.

PETKEVIČIŪTÉ R. 1996: A chromosome study in the progenetic cestode Cyathocephalus truncatus (Cestoda: Spathebothriidea). Int. J. Parasitol. 26: 1211-1216.

PODDUBNAYA L.G. 2002: Ultrastructure of genital system ducts of Diphyllobothrium latum (Cestoda: Pseudophyllidea): the ducts of the female reproductive system. Parazitologiya 36: 79-87. (In Russian.)

PODDUBNAYA L.G. 2003a: Structure of reproductive system of the amphicotylid cestode Eubothrium rugosum (Cestoda, Pseudophyllidea). J. Evol. Biochem. Physiol. 39: 345-355.

PODDUBNAYA L.G. 2003b: Ultrastructure of reproductive organs and ducts in the progenetic species Archigetes sieboldi (Cestoda, Caryophyllidea). Zool. Zh. 82: 10381050. (In Russian.)

PODDUBNAYA L.G., MACKIEWICZ J.S., BRUŇANSKÁ M., DEZFULI B.S. 2005: Fine structure of the male reproductive ducts, vagina and seminal receptacle of $C y$ athocephalus truncatus (Cestoda: Spathebothriidea). Folia Parasitol. 52: 241-250.

PODDUBNAYA L.G., MACKIEWICZ J.S., KUPERMAN B.I. 2003: Ultrastructure of Archigetes sieboldi (Cestoda: Caryophyllidea): relationship between progenesis, development and evolution. Folia Parasitol. 50: 275-292.

PROTASOVA E.N., ROYTMAN V.A. 1995: [Cyathocephalates, tapeworm helminthes of marine and freshwater fish (Cestoda: Pseudophyllidea: Cyathocephalata). Essentials of Cestodology. Vol. 12.] Institute of Parasitology, Moscow, Russian Academy of Sciences, 134 pp. (In Russian.)

SCHMIDT G.D. 1986: Handbook of Tapeworm Identification. CRC Press, Boca Raton, Florida, 675 pp.

SCHMIDT J. 1996: Complex carbohydrates in shell precursor globules of the vitellarium and at the eggshell of $\mathrm{Hy}$ menolepis microstoma (Cestoda). Parasitol. Res. 82: 157164.

ŚWIDERSKI Z., BRUŇANSKÁ M., PODDUBNAYA L.G., MACKIEWICZ J.S. 2004: Cytochemical and ultrastructural study on vitellogenesis in caryophyllidean cestode Khawia armeniaca (Cholodkovski, 1915). Acta Parasitol. 49: 16-24.

ŚWIDERSKI Z., CONN D.B. 1999: Ultrastructural aspects of fertilization in Proteocephalus longicollis, Inermicapsifer 
madagascariensis, and Mesocestoides lineatus (Platyhelminthes, Cestoda). Acta Parasitol. 44: 19-30.

ŚWIDERSKI Z., CONN D.B., MIQUEL J., MŁOCICKI D. 2004: Fertilization in the cestode Gallegoides arfaai (Mobedi et Ghadirian, 1977) Tenora et Mas-Coma, 1978 (Cyclophyllidea, Anoplocephalidae). Acta Parasitol. 49: 108115.

ŚWIDERSKI Z., TKACH V. 1997: Differentiation and ultrastructure of the paruterine organs and paruterine capsules in the nematotaeniid cestode Nematotaenia dispar (Goeze, 1782) Lühe, 1910, a parasite of amphibians. Int. J. Parasitol. 27: 635-644.

ŚWIDERSKI Z., XYLANDER W.E.R. 2000: Vitellocytes and vitellogenesis in cestodes in relation to embryonic devel-

Received 5 August 2004 opment, egg production and life cycle. Int. J. Parasitol. 30: 805-817.

TAPPENDEN T., KEARN G.C., EVANS-GOWING R. 1993: Fertilization and the functional anatomy of the germarium in the monogenean Entobdella soleae. Int. J. Parasitol. 23: 901-911.

XYLANDER W.E.R. 1988: Ultrastructural studies on the reproductive system of Gyrocotylidea and Amphilinidea (Cestoda). I. Vitellarium, vitellocyte development and vitelloduct in Amphilina foliacea (Rudolphi, 1819). Parasitol. Res. 74: 363-370.

YAMANE Y., NAKAGAWA A., MAKINO Y., HIRAI K. 1983: Diphyllobothrium latum: scanning electron microscopic study on the eggshell formation. Jpn. J. Parasitol. 32: $13-25$.

Accepted 15 November 2004 